\title{
DRAINAGE EVOLUTION AND RIVER FLOODING RELATED TO TECTONIC AND HUMAN ACTIVITIES
}

\author{
A. ZELILIDIS
}

\section{ABSTRACT}

Flooding events accompanied by destruction of human infrastructure many times are related with evolution of river drainage. If towns were built or will be built on or near an abandoned channel it is dangerous because if this channel is the misfit element of a reverse drainage basin, it could change again to its original flow forming a re-established drainage. In this case, the abandoned channel could become active, and in the area of the wind gap large gorges could be formed, with consequent impact on human activities. Also, we can predict that in the next e.g. ?100 years: a) The reverse drainages of Olvios and Rethis rivers, will remain stable, whereas the antecedent drainage of Piros and Selemnos rivers could change to a reverse drainage.

KEY WORDS: Drainage evolution, flooding, human activities, Corinth graben

\section{INTRODUCTION}

Tectonic activity in northern Peloponnesus has migrated basinwards, with the footwall of active faults being uplifted and backtilted (Poulimenos et al., 1993). Tectonic activity seems to be stronger in the west than in the east. Quaternary sediments exposed in the uplifted southern part of the Corinth graben (Fig.1B) consist, from south to north, of alluvial fan and lacustrine conglomerates near the graben margins. Fan-delta conglomerates (Gilbert- or trapezoidal- types, according to Poulimenos et al., 1993; Zelilidis \& Kontopoulos, 1996) and marls, deposited in the middle part of the graben. Lacustrine marls overlain by thin marine or fluvial sediments have formed terraces near the present coastline (Doutsos and Piper, 1990).

This paper builds on an earlier work (Zelilidis, 2000) on drainage evolution in this developing graben. In the earlier work 41 river drainage basins were studied in northern Peloponnesus and classified into four types: antecedent, multistory, re-established and juvenile drainage basins (see Table 1 in Zelilidis, 2000). Antecedent drainage is when a river has maintained its original direction of flow across later tectonic topography. Multistory drainage consists of a re-established drainage and of a reverse drainage. Reverse drainage, when the flow direction along part of a river is reversed, consists of two opposing drainage components: a misfit and a reverse element; the area between these two elements, termed "wind gap", is a dry valley. Re-established drainage is when reverse elements return to their original flow direction. Juvenile drainage consists of small incising and headword-eroding streams.

Their evolution was influenced by the presence of intrabasinal basement highs and transfer faults, and by the distance from the source, the sediments that the river cross-cuts, and the uplift rate. (a) Where the sediments that the river cross-cuts were the soft uncohesive lacustrine marls, that are easily eroded, then the drainage remained stable as an antecedent-type. (b) Where the sediments were cohesive sandy marine terraces or the coarse-grained deposits or the Pre-Neogene basement and erosion was difficult then an antecedent drainage could change to a reverse drainage. (c) In the case when the distance from the source was close and the river power was strong then independently of the lithologies the antecedent drainage remained unchanged. (d) In the case that the drainage changed due to the lithologies from an antecedent to a reverse, then depending on the presence of transfer faults in the area of the reverse element, the reverse drainage could be changed into reestablished. In the case that transfer faults were absent then the reverse drainage would remain unchanged. Multistory drainage results when a river drainage changed along its flow at least two or three times. (e)Independently of the lithologies, the distance from the source, the presence of the transfer faults and the uplift rate, antecedent drainage might change to a reverse drainage due to the synchronous activity of synthetic and antithetic faults within to the basin forming intrabasinal basement highs that separated the river drainage.

The aim of this paper is to examine how human activities influence drainage evolution. This paper examines if there are towns or villages in northern Peloponnesus that can be flooded in the future due to the human activities.

1. Department of Geology, University of Patras, 26500 Patras, Greece. Tel., Fax: 061 996272; E-mail: A.Zelilidis@upatras.gr 


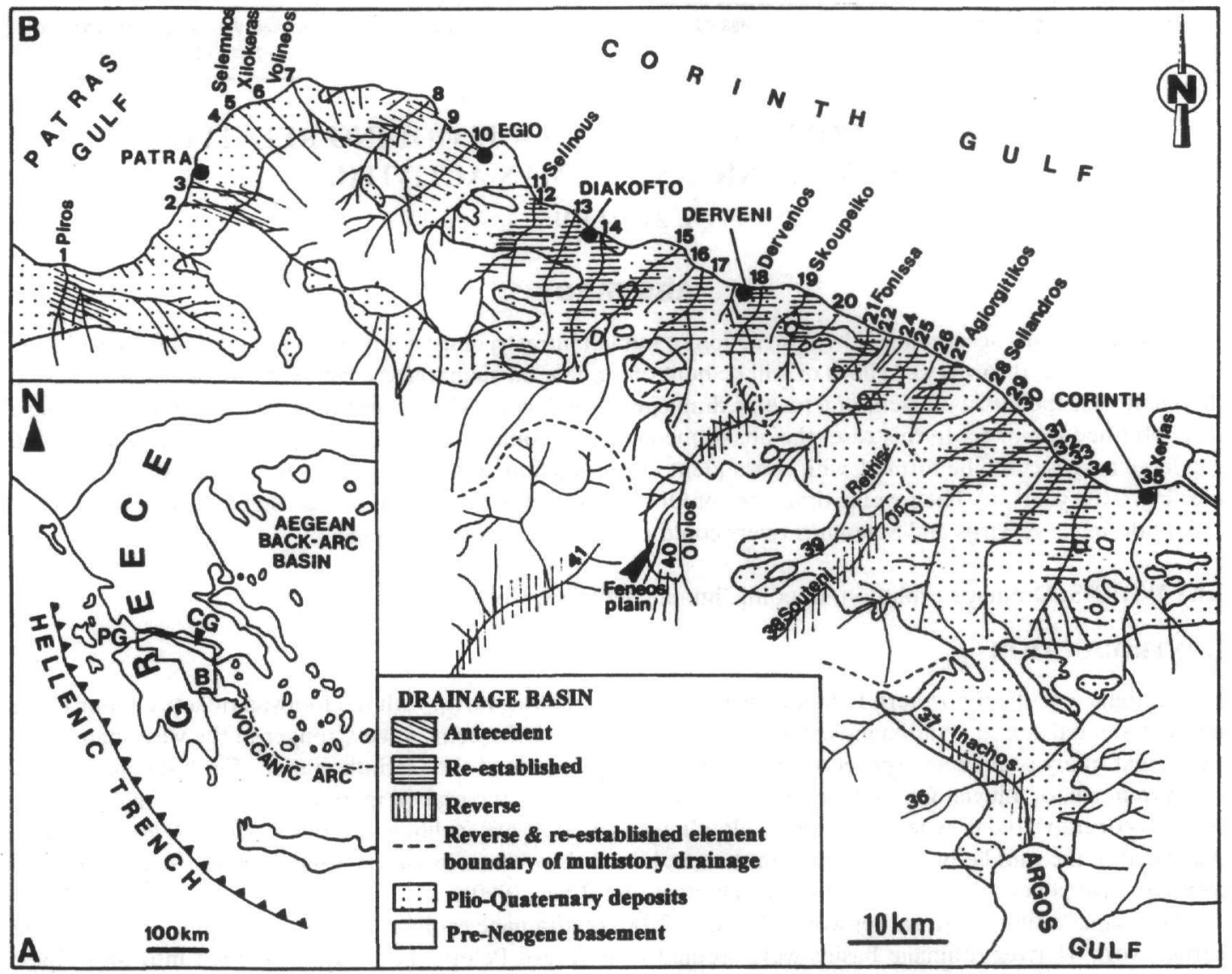

Fig.1: A. General map of Greece, showing the studied area, and the Corinth (C.G) and Patras (P.G) grabens, B. Geological map of the northern part of Peloponnesus showing the 41 rivers, the distribution of the four drainage types, and the Quaternary sediment facies distribution.

\section{GEOMORPHOLOGICAL DATA}

In the studied area, maximum altitudes reached are 2200m (Fig. 2). Most of the Plio-Quaternary deposits are situated between the 0 and $600 \mathrm{~m}$ contours, trending in a WNW direction (Patras and Corinth sub-basins) or in a NE direction (Rion sub-basin), parallel to trends of master faults (Figs. 1B;2). The continuity of the WNW and NE directions of contour lines is interrupted by lesser NNE or NW trends respectively, which are parallel to the direction of the transfer faults. Contour lines on the Pre-Neogene basement show the same directions as in the Plio-Quaternary deposits, but are more irregular.

Uplift rates, calculated for Quaternary terraces, differ along the Corinth-Patras rift. According to Stamatopoulos et al. (1994) the uplift rate in Patras sub-basin (Fig. 3) is about $0.8 \mathrm{~mm} / \mathrm{yr}$; whereas near Patras town this is about $1 \mathrm{~mm} / \mathrm{yr}$ (Piper et al., 1990). The highest uplift rate was calculated in Rio sub-basin (Fig. 3) and is 4.5-6 mm/yr (Kontopoulos and Zelilidis, 1997). Uplift rate for Corinth sub-basin decreases eastwards and from 2.2mm/yr near Egio (Frydas, 1991; Poulimenos et al., 1993), 1.5mm/yr in the central part of the basin (Doutsos and Piper, 1990), decreases to 0.3-0.4mm/yr near Corinth town (Keraudren and Sorel, 1987; Armijo et al., 1996; Dia et al., 1997) (Fig. 3).

A relative erosion rate was calculated, between the river valley and adjacent areas, either in the area of the wind gap or on the footwall and adjacent to the active faults. The calculation of the erosion rate is based on the difference between valleys and adjacent areas altitudes that formed in specific time spans. Erosion rate in the area of the wind gap in the multistory drainages is calculated between 0.8 and $1.2 \mathrm{~mm} / \mathrm{yr}$. Uplift rate in these rivers is about $1.5 \mathrm{~mm} / \mathrm{yr}$. In the antecedent Piros and Selemnos drainage relative erosion rate near the coast and on the footwall of the active fault is $0.4 \mathrm{~mm} / \mathrm{yr}$ and $2 \mathrm{~mm} / \mathrm{yr}$, respectively. Uplift rate of Piros and Selemnos 
drainage is about $0.8 \mathrm{~mm} / \mathrm{yr}$ and $4.5-6 \mathrm{~mm} / \mathrm{yr}$, respectively. In all studied cases the ratio, erosion rate to the uplift rate is $<1$ (about $1 / 2$ ).

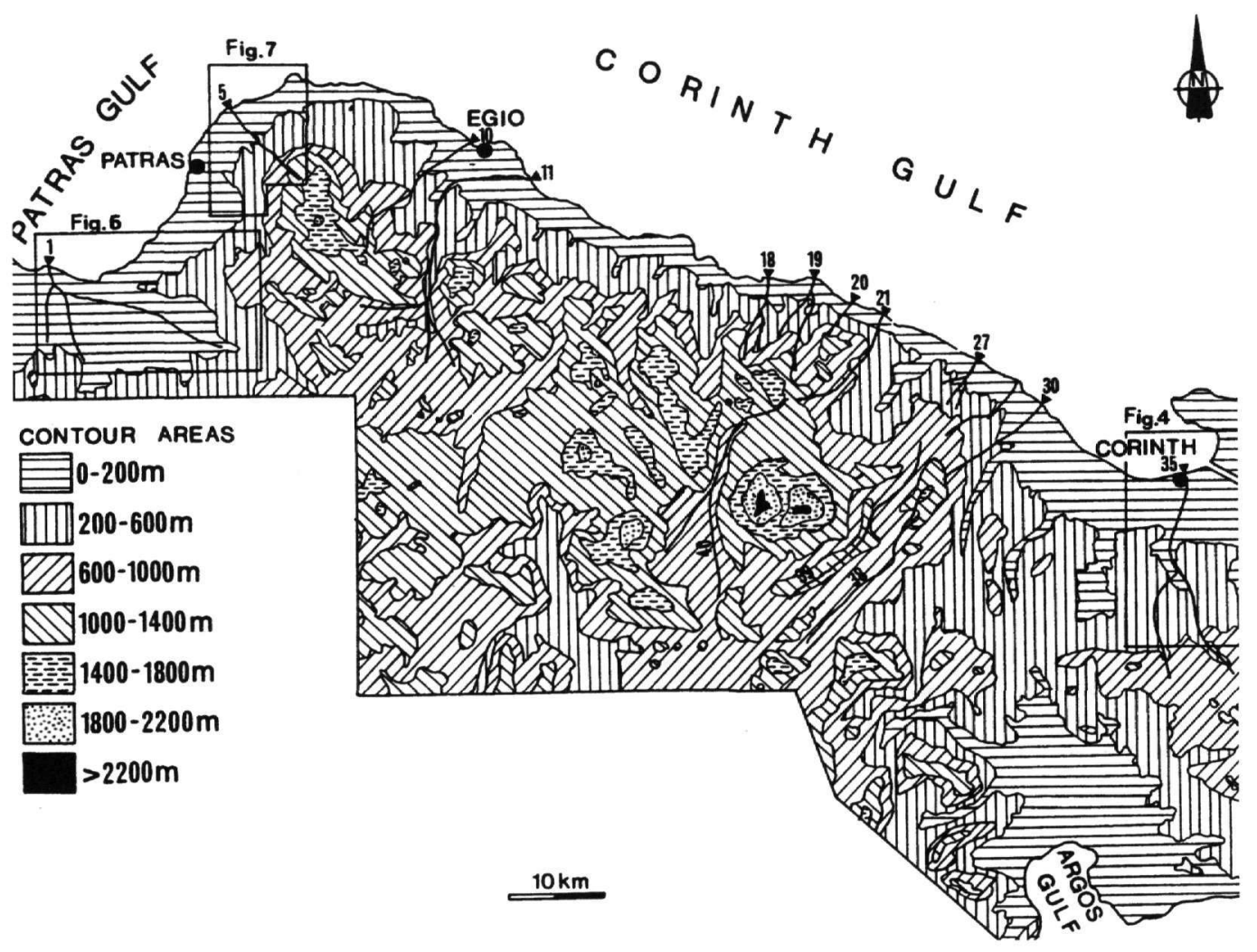

Fig. 2: Contour map of the studied area.

$\begin{gathered}\text { Patras } \\ \text { sub-basin }\end{gathered}$
sub-basin

A. Kastritsi

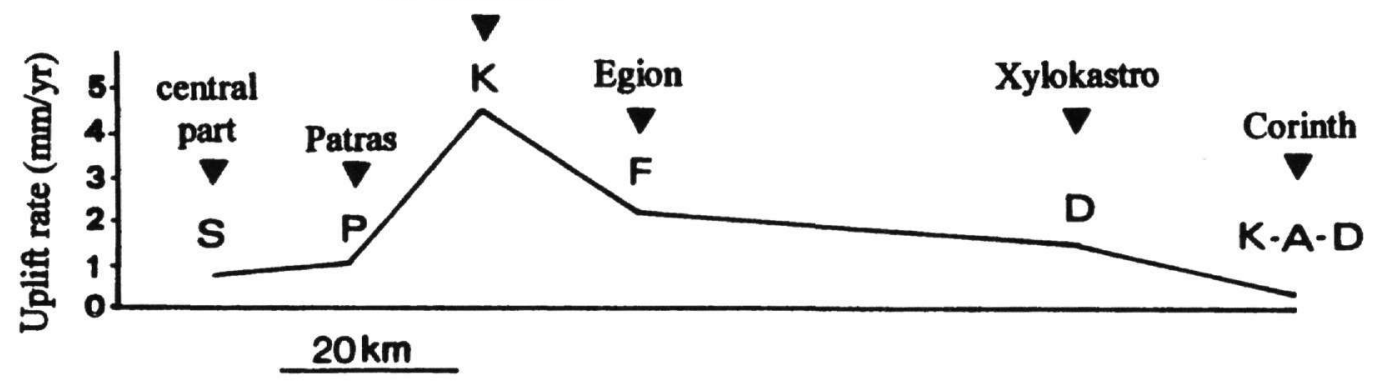

Fig. 3: Schematic section showing uplift rates along Corinth graben. Letters correspond to $S=$ Stamatopoulos et al., 1994; $P=$ Piper et al., 1990; $K=$ Kontopoulos and Zelilidis, 1997; $F=$ Frydas, 1991; $D=$ Doutsos and Piper, 1990; K-A-D = Keraudren and Sorel, 1987; Armijo et al., 1996; Dia et al., 1997). 


\section{HUMAN INFRASTRUCTURE RELATED WITH RIVER DRAINAGE EVOLUTION AND RIVER FLOODING}

\section{3.a. Could the recent flooding of Xerias river in 12/1/1997 related with human activities?}

According to Zelilidis $(1998,2000)$ the re-established Xerias river drainage during Holocene formed a reverse drainage. The wind gap area was situated in the footwall of the active L4 fault (Fig. 4) and the block between L3 and L4 faults back-tilted forming the area where the reverse element was developed. The Holocene reverse element channel width in few places is up to $130 \mathrm{~m}$ but the cultivation of crops within the channel and the building of bridges have reduced channel width to $10-15 \mathrm{~m}$ and so the river was flooded. New Corinth town was developed on the Holocene misfit element (Fig.5).

In the area of the wind gap, near the town of New Corinth, the original width of the Xerias river 100 years ago was $<4 \mathrm{~m}$. At present it is between $12-18 \mathrm{~m}$ wide and its depth between $1.5-3 \mathrm{~m}$. Human activities (two narrow bridges were built) in this area reduced its depth and width, and stopped the evolution and the change of the Xerias river from reverse to re-established drainage (Fig. 5). The Xerias river is trying to form a wider and deeper channel as it was before change from antecedent to reverse drainage.

Moreover, due to human activities, the rate of erosion in the area of the wind gap was minimized and also, secondary channels of the old misfit element were abandoned.

During 12/1/1997, strong rainfall flooded the Xerias river and: 1) destroyed crops and bridges, in the area of the old reverse element, and returned the channel geometry to its original configuration (130m wide), and 2) in the area of the wind gap, flooding of the Xerias river resulted mostly from its original geometric evolution and less to human activities. Its original geometry was not quite enough to accept the large amounts of material that the river transported. Human activities which reduced also the channel geometry in the area of the wind gap, and minimized the rate of erosion decreased the channel capacity and increased the problems. Moreover, channel capacity discharged on the roads where the pre-existing secondary channels were abandoned.

With time, the Xerias river will try to produce larger gorges in the area of the wind gap as a result of its evolution (subsidence of the hangingwall of the L4 fault and uplift of the footwall respectively), producing more problems for the town of Corinth. It seems that Xerias river drainage basin started its return to the original flow direction before 100 years B.P. and so the erosion of the wind gap area will continue until the river reaches its final configuration. As a consequence of active tectonics in the area of Corinth town, people must be ready to accept the results of destruction due to this evolution.

\section{3.b. How could river drainage evolve in the future?}

Two antecedent river drainages were studied (Piros and Selemnos) in order to see how human activities within the river drainage influence the rate of erosion and change the pattern of evolution. Moreover, the reverse drainages of Olvios and Rethis rivers, have been studied in order to predict if they could be changed to reestablished drainages.

3.b.1. Piros river (Fig. 6): Pre-existing conditions: Piros river is situated in the Patras sub-basin (Fig. 1B) and its drainage basin is within Plio-Quaternary deposits between 0-200 $\mathrm{m}$ altitude. This river evolved in a narrow basin, influenced by ENE- and WNW- trending faults (Zelilidis et al., 1988) filled with upper Pliocene shallow marine fine-grained deposits (Zelilidis et al., 1988; Frydas, 1989). During the early Pleistocene the basin was covered by alluvial fans (situated mostly towards the southern margins) and braided river coarse-grained deposits and lacustrine fine-grained deposits. Finally the basin was inundated during late Pleistocene and marine finegrained deposits accumulated (Stamatopoulos et al., 1994). The direction of Piros river flow and the outcrops of old deposits are aligned in WNW directions, parallel to WNW directed master faults. Transfer- or antitheticfaults are few or absent. The Piros river drainage is characterized by a low late Quaternary uplift rate $(0.8-1 \mathrm{~mm} /$ yr) and gorges less than $30 \mathrm{~m}$ deep.

The evolution of the Piros drainage within the Patras sub-basin is very different from the others studied in the Corinth sub-basin. The fact that the Piros river flows parallel to the master faults and the absence of transfer- and antithetic- faults are the reasons that the Piros river never changed its flow direction. The fact that gorges are shallow could be related with low uplift rates.

Present conditions: Human activities that took place within the drainage basin and in relation to the erosion could separate Piros drainage in two areas, the area of the coastline and the area close to the coastline.

Erosion along the coastline now is minimized due to human infrastructures, including cement buildings, roads e.t.c. On the other hand, agricultural activities behind the coastline have increased the rate of erosion. Moreover the fact that people remove sediments from the river channel, produce daily a negative relief in the area behind the coastline. 


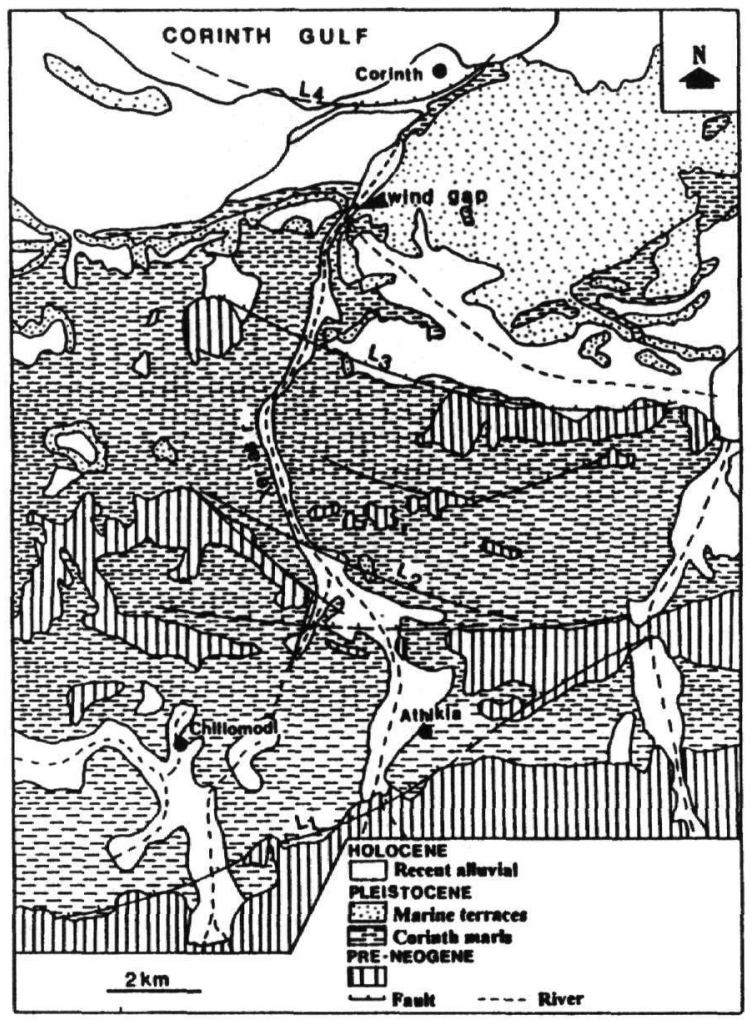

Fig. 4: Geological map of the easternmost studied area, modified from Zelilidis $(1998,2000)$ showing the Quaternary sediment facies distribution, the principal extensional faults, Xerias river drainage basin and the area of the wind gap. For location see figures $1 B$ and 2.

As before $1000-2000$ yrs

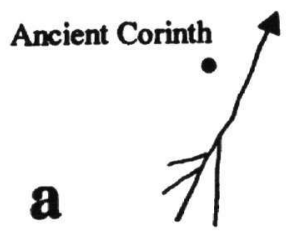

As before 100 yrs

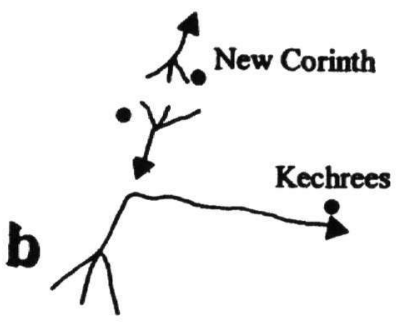

Today

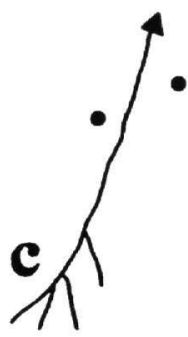

Fig. 5: Diagram showing the evolution of the Xerias drainage in three stages: (A) antecedent drainage, (B) reverse drainage, and $(C)$ re-established drainage.

Drainage evolution in the future: In the next ?100 years probably and although uplift rate is low, the nowadays coastline will form an area of a wind gap due to the absence of erosion and the Piros antecedent drainage will be changed to a reverse drainage. In this case the area southwards of the wind gap will be inundated from the river and a lake will be formed due to increased erosion and removal of sediments from the Piros channel.

3.b.2. Selemnos river (Fig. 7). Pre-existing conditions: It is situated in Rion sub-basin (Fig. 1B) and its drainage evolution was influenced by the evolution of this sub-basin. The upper reaches within Pre-Neogene basement are in an area of 600-1000 m altitude, whereas the lower reaches are situated between 0-600m within Plio- 


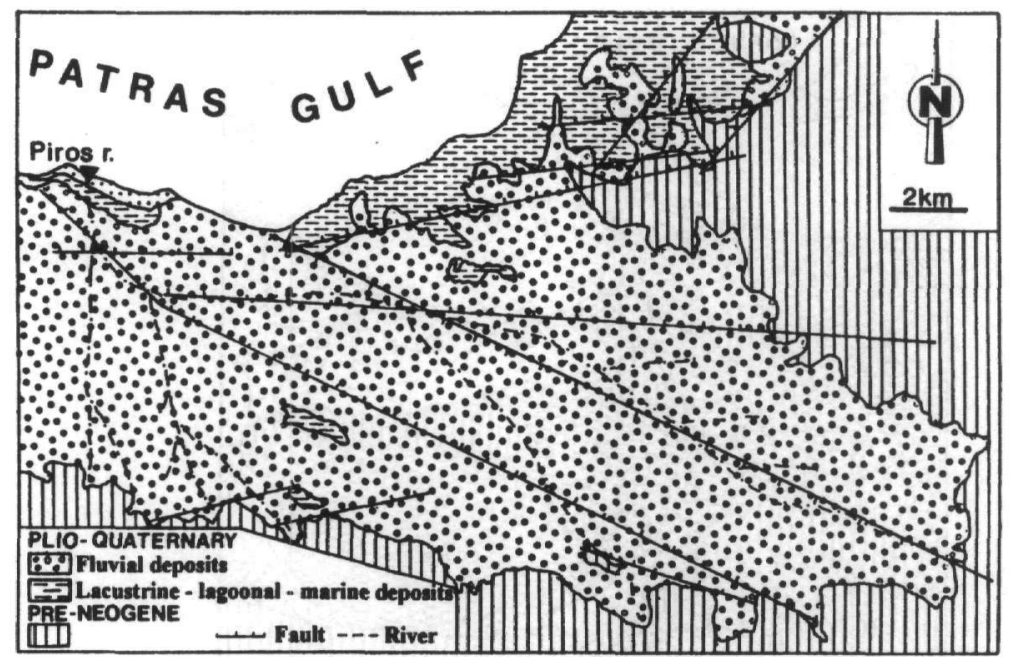

Fig. 6: Geological map, modified from Zelilidis et al. (1988), of the westernmost stu-died area, showing the sediment that the antecedent drainage Piros river cross-cut and the area that could change to a lake. For location see figures $1 B$ and 2.

Quaternary deposits (Fig. 2). Lower reaches could be separated in two parts, with altitudes $0-100 \mathrm{~m}$ and 100 $600 \mathrm{~m}$ respectively. This river evolved in a narrow basin, influenced by NE-trending faults, filled with PlioPleistocene marine/lagoonal deposits, lower Pleistocene braided river deposits, middle to upper Pleistocene lagoonal deposits and upper Pleistocene alluvial fans (Kontopoulos \& Zelilidis 1997). The flow direction of Selemnos river is aligned in a NW direction due to activity of many transfer faults which have influenced the evolution of sub-environments (Fig. 7). Antithetic faults are few or absent and the tectonic activity migrated northwards, towards the basin center. The Selemnos river drainage is characterized by a high late Quaternary uplift rate ( $>6 \mathrm{~mm} / \mathrm{yr}$.), and gorges up to $300 \mathrm{~m}$ deep with walls more than $70^{\circ}$ steep.

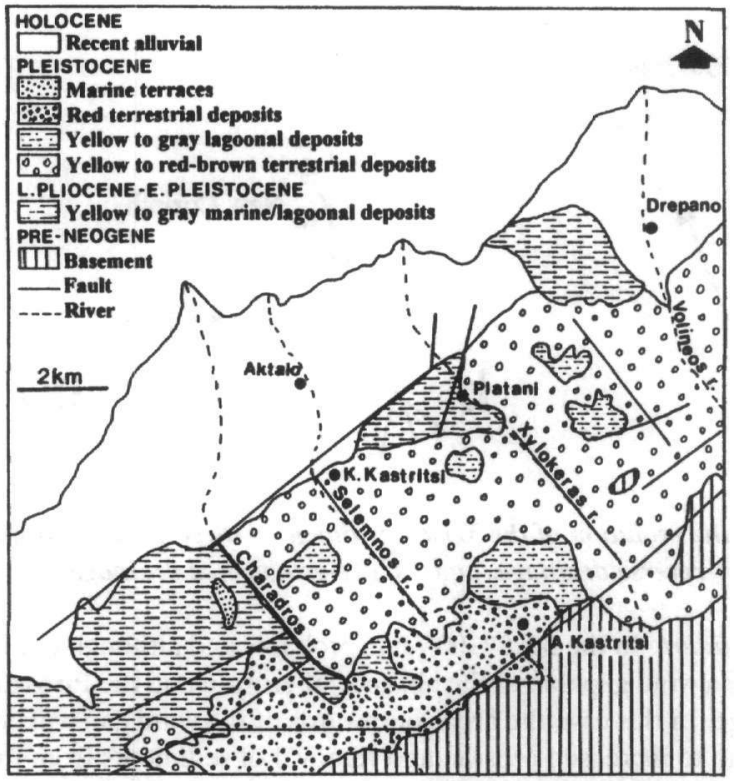

Fig. 7: Geological map, modified from Kontopoulos \& Zelilidis (1997), of the Rion sub-basin, showing the sediments that the antecedent drainage Selemnos river cross-cut and the area that could be changes to a lake. For location see figures $1 B$ and 2. 
The Selemnos river flow remained unchanged through time, in a NW direction parallel to the transfer fault direction. This happened because the basin was narrow, the tectonic activity migrated northwards, and antithetic faults were absent. Deep and steep gorges in the Selemnos river could be related with the coarse-grained deposits that the river flows across and the higher uplift rates, in relation to Piros river gorges and uplift rates.

The lower part of the lower reaches (altitudes between $0-100 \mathrm{~m}$ ) represent a block between two active faults that tilts backwards (Fig 8), and for this reason altitudes remain low. The upper part of the lower reaches represent the area of coarse grained deposits formed during Pleistocene. Holocene alluvial fans were formed in the contact between the above two parts of the lower reaches.

According to Kontopoulos \& Zelilidis (1997) the presence of middle to upper Pleistocene lagoonal deposits in the upper part of lower reaches indicate that the lower Pleistocene land (braided river deposits) subsided due to the reactivation of bounding faults, southwards, and in relation to the activity of intrabasinal antithetic faults, the area was inundated during middle to upper Pleistocene.

Present conditions: Human activities that took place within the drainage and in relation to the erosion could separate the lower reaches of Selemnos drainage in two areas, the area of the coastline and the area of the lower part of lower reaches (Fig. 8a).

Erosion along the coastline now is minimized due to human infrastructures, including cement buildings, roads e.t.c.

On the other hand the lower part of the lower reaches with altitudes $0-100 \mathrm{~m}$ is characterized by: a. the abandonment of smaller channels, b. agricultural activities, c. the fact that people remove sediments from the river channel. All the above factors increased the ratio of erosion in this block behind the coastline. Moreover this block is back tilted forming, without any human activity, a negative relief in the southern part of this block.
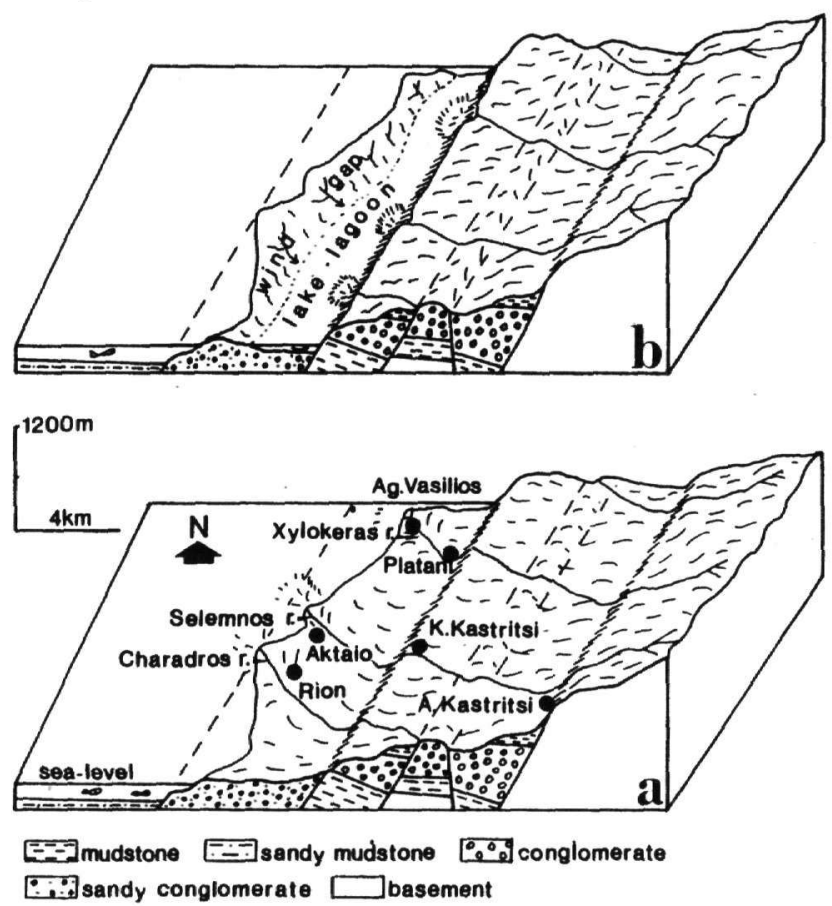

Fig. 8: Block diagrams showing the expected future evolution of the Selemnos drainage pattern.

Drainage evolution in the future: In the next ?100 years, taking into account the high uplift rate, the present coastline will form a wind gap due to the absence of erosion and the Selemnos antecedent drainage will be changed to a reverse drainage, as this happened during middle to upper Pleistocene. In this case the area southwards of the wind gap will be inundated from the river and a lake or a lagoon will be formed due to increased erosion, the removal of sediments of the Selemnos channel and back tilting of this area (Fig. 8b).

3.b.3. Olvios and Rethis rivers (Fig.1B). Pre-existing conditions: During the late Pliocene - early Pleistocene the Olvios and Rethis rivers formed an antecedent drainage. Later during the middle Pleistocene, the Olvios 
and Rethis rivers changed to reverse drainages and then remained unchanged (Doutsos and Piper, 1990).

Present conditions: The present Olvios river forms a reverse drainage with the reverse element discharging into the Feneos plain (Figs. 1B). The wind gap is on thick conglomeratic deposits that have been elevated 1000$1400 \mathrm{~m}$. One of the Dervenios, Skoupeiko and Fonissa rivers probably was the misfit element and the other two were the old juvenile rivers of this reverse drainage.

The present Rethis river consists of the reverse element discharging into Stymfalia Lake. The wind gap is on conglomerates that have been elevated $1400-1800 \mathrm{~m}$, and the Agiorgitikos river was the misfit element.

Drainage evolution in the future: The absence of transfer faults in the wind gap areas, and the fact that the ratio of erosion to uplift rate is $<<1$ in the wind gap area is probably the major reason that Olvios and Rethis reverse drainages could not be changed in the future to re-established drainages.

\section{DISCUSSION AND CONCLUSION}

Flooding events accompanied by destruction of human infrastructure many times are related with evolution of river drainage. If towns were built or will be built on or near an abandoned channel it is dangerous because if this channel is the misfit element of a reverse drainage basin, it could be changed again to its original flow (reestablished drainage). In this case, the abandoned channel would change to active, and in the area of the wind gap large gorges would form, with a consequent impact on human activities.

In an attempt to predict if some of drainages could be changed in the next e.g. 100 years, taking into account that generally Peloponnesus is uplifted and back-tilted, as a result of migration of tectonic activity northwards towards Corinth and Patras Gulfs, and the ratio of erosion to uplift rate is $<1$ in the wind gap area, then: a) The reverse drainages of Olvios and Rethis rivers, would be stable as reverse drainages, whereas b) the antecedent drainage of Piros and Selemnos rivers could change to a reverse drainage.

Due to the change of the antecedent drainage to reverse drainage the discharge area of the reverse element (back tilted block) could become lake or lagoon, as this is indicated for Piros and Selemnos antecedent drainages, as this happened to Xerias river drainage. The direction of the new river flow will be parallel to the bounding fault and its direction will depends on the fault escarpment.

\section{ACKNOWLEDGMENTS}

I would like to thank Dr. H. Maroukian and the anonymous reviewer for their critical discussion and comments on the manuscript.

\section{REFERENCES}

ARMIJO, R., MEYER,B., KING,G.C.P., RIGO,A., PAPANASTASSIOU,D., 1996. Quaternary evolution of the Corinth Rift and its implications for the Late Cenozoic ev'olution of the Aegean. Geophys. J. Int., 126, 11-53.

DIA, A.N., COHEN,A.S., O'NIONS,R.K., JACKSON,J.A., 1997. Rates of uplift investigated through ${ }^{230}$ Th dating in the Gulf of Corinth (Greece). Chemical Geology, 138, 171-184.

DOUTSOS, T., PIPER, D.J.W., 1990. Listric faulting, sedimentation, and morphological evolution of the Quaternary eastern Corinth rift, Greece: First stages of continental rifting. Geol.Soc.Am.Bull., 102, 812-829.

FRYDAS, D., 1989. Biostratigraphische Untersuchungen aus dem Neogen der NW- und W-Peloponnes, Griechenland. N.Jb.Geol.Palaont.Mh., H6, 321-344.

FRYDAS, D., 1991. Palaookologische und stratigraphische untersuchugen der diatomeen des Pleistozans der NPeloponnes, Griechenland. Bull.Geol.Soc.Greece, XXV/2, 499-513.

KERAUDREN, B., SOREL, D., 1987. The terraces of Corinth (Greece) - A detailed record of eustatic sea-level variations during the last 500.000 years. Marine Geology, 77, 99-107.

KONTOPOULOS,N., DOUTSOS,T., 1985. Sedimentology and Tectonics of the Antirion area (Western Greece). Bull.Soc.Geol.It., 104, 479-489.

KONTOPOULOS,N., ZELILIDIS,A., 1997. Depositional environments of the coarse-grained lower Pleistocene deposits in the Rio-Antirio basin, Greece. In: Marinos, G.C. Koukis, G.C. Tsiambaos, Stournaras G.C. (Eds.), Engineering Geology and the Environment. Proc. Int. Symp. Eng. Geol. Env. A.A.Balkema, Rotterdam, 199204.

PIPER, D.J.W., STAMATOPOULOS, L., POULIMENOS, G., DOUTSOS, T., KONTOPOULOS, N., 1990. Quaternary history of the Gulfs of Patras and Corinth, Greece. Z. Geomorph.N.F., 34, 451-458.

POULIMENOS, G., ZELILIDIS, A., KONTOPOULOS, N., DOUTSOS, T., 1993. Geometry of trapezoidal fan deltas and their relationship to extensional faulting along the south-western active margins of the Corinth rift, 
Greece. Basin Research, 5, 179-192.

STAMATOPOULOS,L., VOLTAGGIO,M., KONTOPOULOS,N., 1994. ${ }^{238} \mathrm{Th} /{ }^{238} \mathrm{U}$ Dating of Corals from Tyrrhenian marine deposits and the Palaeogeographic evolution of the Western Peloponnesus (Greece). Munster. Forsch. Geol. Palaont., 76, 345-352.

ZELILIDIS, A, 1998. Xerias river evolution in relation to the geological background of the Corinth basin and its flooding in 12/1/1997. Bull.Geol.Soc.Greece, 32 (1), 277-286.

ZELILIDIS, A., 2000. Drainage evolution in a rifted basin, Corinth graben, Greece. Geomorphology, 35, 69-85.

ZELILIDIS, A., KOUKOUVELAS, I., DOUTSOS,T., 1988. Neogene paleostress changes behind the forearc fold belt in the Patraikos Gulf area, Western Greece. N.Jb.Geol.Palaont.Mh., 5, 311-325.

ZELILIDIS, A., KONTOPOULOS, N., 1996. Significance of fan deltas without toe-sets within rift and piggyback basins: examples from the Corinth graben and the Mesohellenic trough, Central Greece. Sedimentology, 43, 253-262. 